\title{
La Paz School
}

From a Ghetto to a Magnet School

\section{Javier, Díez-Palomar, Tatiana Santos Pitanga, and Pilar Alvarez Cifuentes}

\begin{abstract}
This article presents the transformation process of San Juan, a ghetto school, into La Paz, a magnet school. This transformation has been made possible by implementing the communicative methodology of research (CMR) based on the participation of everyone involved in the research process, together with the administration and the researchers. The article explains how the change has been made as well as the political measures that have been developed. Finally, a reflection considering the political improvements arising from the experience is given.
\end{abstract}

Keywords: communicative methodology of research, Roma, Albacete, INCLUDED, adult education, La Paz school, learning communities

\section{Introduction}

In November 2009, while part of the INCLUD-ED team was at the European Parliament in Brussels preparing the first European conference on the project, one of the activists who had been most involved in the transformation of the La Milagrosa neighbourhood in Albacete, Spain, explained to us the process of social change developed in this area. La Milagrosa is one of the poorest neighbourhoods in Spain, with high levels of conflict. The situations of violence and delinquency in this area are normally shown in the media. However, Ángel, ${ }^{1}$ someone from La Milagrosa who was in Brussels with us, had a completely different story - one of hope. La Milagrosa had been on the news as an exemplar neighbourhood, a place undergoing a transformation thanks to the school. The news explained that the school had obtained the Quixote prize, awarded by the Secretariado Gitano Foundation in Spain, as recognition of its integration work with the Roma community. Ángel was really touched. He had known the neighbourhood in its hardest times. He had been witness to when the education authorities decided to close the school. And now he was witness, and a claimant, to the process of transformation. He told us: 
I was in the house of a Roma family. The children were in the dining room. Manuel, the small one, was teaching his brother Antonio to write. Manuel is 5 years old. Antonio, who is 9 , was in the school before its transformation in the learning community. He hardly knows how to write his name. Manuel, however, can read without problems.

All those present were moved to tears.

This example illustrates what has happened in the San Juan school, currently known as La Paz school. In this school, administrators, families, and professionals involved in community social organisations worked together to change the deteriorating situation. They contacted CREA, Centre of Research in Theories and Practices that Overcome Inequalities, which guided them in the implementation of proven successful actions approved by the international scientific community and based on the rigorous implementation of the communicative methodology of research (CMR).

From then onwards, everything started to change, and the dream became possible. Antonio had attended a ghetto school with high levels of violence and conflict between teachers and families, etc. Antonio was 9, almost 10, and he couldn't read or write. However, his little brother, Manuel, has attended a school in the same place, even the same building. But the school had changed. It had become a learning community. The people in the neighbourhood, with the guidance of the CMR, had entered the school. Now they participate in the decision-making and work together with the educational authorities, with the community social organisations, the administration, and the classroom teachers. Manuel, who was 5 , can read and write perfectly.

In this article, we explain the role of the CMR in the transformation of the San Juan ghetto school into the La Paz magnet school. We show how the community members acted as social transformation agents and how this capacity to change turned difficulties into possibilities, as said by Freire. We describe the school transformation and its impact on the neighbourhood as well as the policy decisions that arose from this successful experience. Finally, we reflect on how the implementation of a methodological approach such as the CMR enables not only the construction of knowledge of reality but also a real social transformation, opening new possibilities for the end-users.

\section{Dialogic Knowledge}

Many authors have tried to understand what the key features explaining social change are, using different theoretical frameworks (Beck, Giddens, \& Lash, 1994; 
Castells, 1997; Habermas, 1984, 1987; Nolan \& Lenski, 2004; Parsons, 1952, 1966). The notion of 'social change' is the prerequisite to comprehend the transformation process, leading to the overcoming of social inequalities. People are transformation agents (Freire, 1998), whose interactions and agreements model social structures and systems (Berger \& Luckman, 1968).

Previous research (A. Gómez, Puigvert, \& R. Flecha, 2011) has found that to overcome complex situations such as those experienced in La Milagrosa, dreams and illusions are needed but also science (Freire, 1998), that is, a rigorous analysis that identifies what actions can be successful in improving the academic performance of all students and in overcoming conflicts in the neighbourhood (R. Flecha, 2000). However, some research tends towards the reproduction of inequality. This may occur when a particular epistemological approach fails to create the conditions to produce social change. For instance, merely descriptive studies are often limited to the affirmation of inequality, without providing elements that could effectively lead to social change. CMR provides theoretical, methodological, and epistemological tools and resources that contribute to the dialogic construction of knowledge and reality, jointly with the end-users, as a way of turning inequalities into opportunities. In this way, the language of possibility eliminates structural and systemic barriers and opens horizons for action, which are executed by means of agreements, commitments, and initiatives. The application of CMR generates real examples of social transformation that have given hope to hundreds of people in the neighbourhood.

The case of Albacete perfectly illustrates what differentiates this approach from others. The transformation process from a ghetto school to a magnet school in La Milagrosa is explained in the next section.

\section{Transformation of a Ghetto School into a Magnet School}

La Paz is a community learning school in the city of Albacete, Spain, characterised by dynamism, hope, and joy. Any visitor can see smiling children happily working in the class. Today, for example, they have been working through interactive groups on math. There are four volunteers in the classroom: two mothers, one grandmother, and a young boy, each in charge of a small group of four or five students. This is a very common occurrence in the school. Interactive groups, in the same manner as the 'subcommunities of mutual learners' suggested by Bruner (1996), are heterogeneous in all senses and promote new forms of learning and knowledge building among all the students. This kind of classroom organisation is supported by scientific evidence, based on the work of Vygotsky (1978) in the first third of the 20th century. It is not 
a coincidence that the academic achievement of La Paz students has improved so substantially. By transforming traditionally nonparticipatory environments, such as the regular classrooms, into spaces of interaction and relationship between families, community members, and students, new channels of dialogue and transformation are being established, ones that are highly beneficial in terms of academic improvement (Díez-Palomar \& Molina, 2009; J. Gómez, Latorre, Sánchez, \& R. Flecha, 2006; Gómez González \& Holford, 2010).

Outside the classroom, we are told there is a tutored library with after-school hours. A group of mothers tell us that next week they are participating in a dialogic gathering. The school is such a vivacious place, full of life. Students, teachers, volunteers, family members, and members of the community associations - everybody is present in the school.

Five years ago, La Paz school had another name. It was San Juan school. It was not a learning community. It was just a school in a troubled neighbourhood. A high percentage of the population of La Milagrosa are Roma people, 'mercheros,' ${ }^{2}$ and immigrant families. Most of the active population collect scrap metal or receive social benefits. According to the Secretariado Gitano Foundation, the Roma community makes up $26 \%$ of the population in La Milagrosa and about $80 \%$ in the nearby neighbourhood of La Estrella. Over the years, this neighbourhood has been a focus of crime and drug trafficking and is considered as one of the most marginal areas in Spain. ${ }^{3}$ San Juan school was famous because of its truancy rates, but not only for this reason. School failure rates also were high; in 2006, about $36 \%$ of the students didn't reach the minimum academic standards, and 3 out of 4 students dropped out of school (INCLUD-ED, 2012). This situation has been widely described in other papers (Aubert, 2011; Aubert, Elboj Saso, García Carrión, \& García López, 2010).

In 2006, it was reported that San Juan teachers refused to go to the school without police protection because of the high rates of violence and conflict (Carcelén, 2006). The school was facing an extreme situation (Aubert et al., 2010). The school had reached truancy rates of $73 \%$, with only 45 students out of 105 regularly attending classes (INCLUD-ED, 2012). Under those circumstances, school closure was considered. It was at that time that the school decided to contact CREA, the Centre of Research in Theories and Practices that Overcome Inequalities, to find a way out of that untenable situation. Ramón Flecha, main researcher of the INCLUD-ED project, visited the neighbourhood to see the situation first-hand (Padrós, García, de Mello, \& Molina, 2011). That opened the door to change. A meeting was held with various members of the community, education authorities, and a group of researchers. Together, they established the basis for a dialogue process by holding several 
meetings aimed at determining the best solution for the problem. Jointly, it was decided to launch a new educational centre, equipped with a team of trained professionals committed to the implementation of all of the educational activities supported by scientific success (Aubert et al., 2010) as proven by INCLUD-ED conclusions. The solution was to implement all of them - not partially, but every single one. After the initial meeting, an advisory committee was created. Thus, transformation started with the implementation of the communicative organisation of research. That was also the first step towards constructing a dialogic knowledge of the situation.

As a result of this process involving an egalitarian dialogue between everyone participating in the transformation of the school, a dialogic inclusion contract was established. The contract stipulated the following: (a) transformation would be based on successful actions, (b) the research team would be responsible for providing this knowledge, (c) the implementation of these actions would be based on dialogue with people in the neighbourhood, and (d) decisions would be made by democratically elected figures within the community (Aubert, 2011; Padrós et al., 2011).

The first decision was to close the school. Immediately after, the school reopened with a new name, La Paz, as well as a new teaching team. This process has been reported more extensively elsewhere (Aubert et al., 2010). After eight months, in May 2007, a meeting was held to assess the transformation process with the participation of students, families, teachers, community members, administrators, political figures, and researchers. Lorena, a fourth-grade Roma student, shared the following observations:

Now we are a learning community, and we are very pleased. We celebrate assemblies where we can make agreements. We have finally elected our class representatives and rules as well as the name of the school. Everything has changed. We have school trips now. We have new teachers. There are volunteers that help us, and the school is happier.

The evidence of academic improvement in La Paz demonstrates the effectiveness of this form of school organisation. The literacy competencies assessment conducted with second- and third-grade students in 2007 and 2008 showed a great improvement in reading skills (from 1.4 in 2007 to 3 out of 5 in 2008), verbal expression (from 1.8 to 3.8 out of 5), and writing (from 0.5 to 2.8 out of 5 ). In math skills, an improvement has been noted in all of the assessment categories, such as measures (from 0.9 to 2.5 out of 4), operations (from 0.4 to 2.7 out of 4), and numbers (from 0.2 to 2.1 out of 4), amongst others. Beyond the academic results, the school transformation succeeded in reducing conflict and improving coexistence as well as in combating 


\section{Evolution of enrollment}

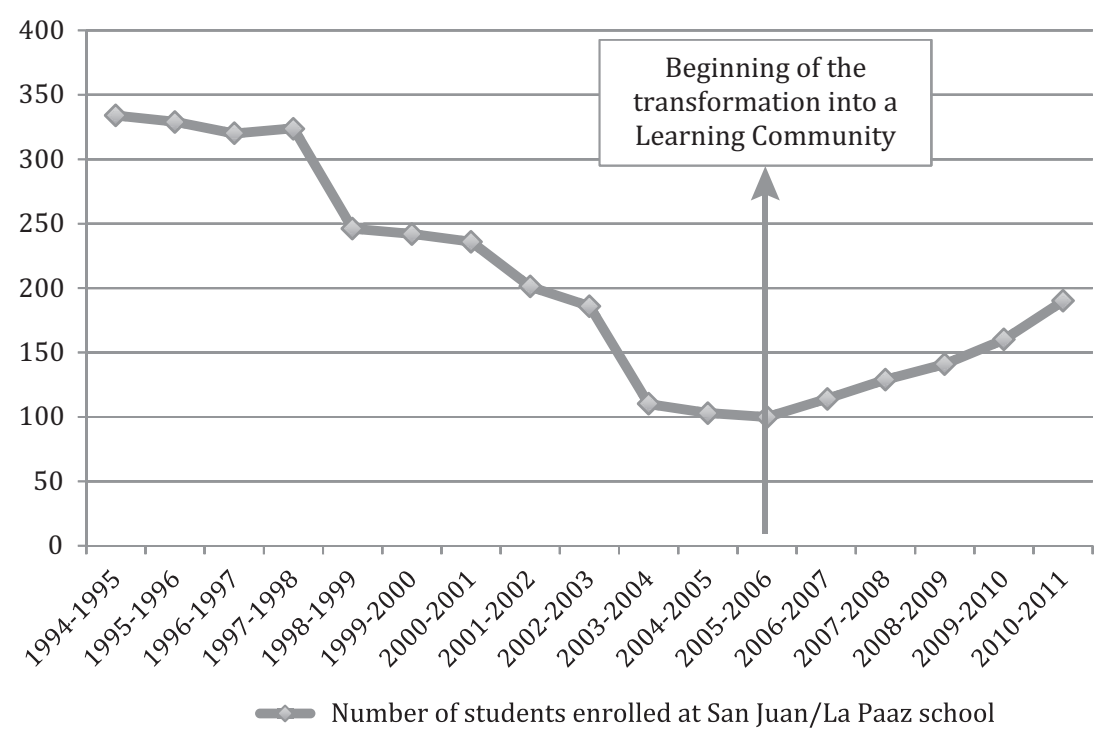

Graph 1. Source: García Carrión, R. (2011)

truancy. All of these educational improvements, deriving from the implementation of successful actions, increase families' confidence in the value of education, as shown by the rise in enrolment rates.

For the first time, the school was being forced to "reject" new students because classrooms were crowded. La Paz school has gone from having high levels of truancy to attracting students from other parts of the city because of the excellent academic results obtained there. The magnet effect is exemplified by the classroom saturation, an entirely new phenomenon in the school. This shows that La Paz school has become a magnet school with a strong pull factor in the local community, and at the same time it refutes the false assumption that ghetto schools are formed because of the concentration of ethnic minorities with low academic skills as well as a lack of interest in improving children's educational opportunities.

\section{Social and Political Impact}

During the first INCLUD-ED Conference in the European Parliament in November 2009, a group formed by researchers, experts, and residents explained the transformation that was taking place in La Milagrosa to dozens of representatives of the 
European Parliament. Evidence based on personal narratives showing the way out of the ghetto were presented. The implementation of the CMR had achieved not only an unprecedented insight into the processes of exclusion and marginalization entrenched in the neighbourhood but also the identification of concrete actions for breaking the cycle of exclusion by creating real possibilities for transformation. As said by one of the residents of the neighbourhood, 'out of all the bad things in this neighbourhood, the best thing is the school'. Data presented by CREA were conclusive: drastic truancy reduction, learning improvement, and conflict reduction within and outside of school.

The successful transformation of the school did not go unnoticed by Albacete's political leaders. In 2009, the results led the Albacete city council to seek advice from CREA to apply those successful actions in the transformation of the whole neighbourhood. The events in the school show that transformation is possible. CMR guidelines are now applied to the transformation of an entire city. A cooperation agreement is established through which the research centre provides scientific evidence of those actions that are successful in transforming and overcoming inequalities. The key is the inclusion of all people in the change process. After two years of joint work by administrators, neighbours, organisations, families, professionals, politicians, etc., data indicate a clear improvement in the living conditions and opportunities in the neighbourhood.

Much of this evidence was presented at the final conference of INCLUD-ED, held in the European Parliament in December 2011. One of the residents of La Milagrosa, who had been in prison, sat in the European Parliament in front of political and social representatives of the EU member states. His moving words were the strongest evidence of his personal narrative of transformation. He explained how participating in the school as a volunteer changed his life, leading him to regain an active role in his community. Establishing interactions with other members of the community had a positive impact on his identity (Mead, 1934). In his speech, he talked about different activities emerging from the transformation of the school into a learning community. Specifically, he referred to a work reintegration experience, which is one of the initiatives created by people in the neighbourhood to build new opportunities. Social impact is also shown through the creation of various services around La Paz, including the Finde centre (aimed at the extension of learning time on weekends), as well as a social fund designed to help people without resources. All of the actions identified by INCLUD-ED (Alexiu \& Sordé, 2011; A. Flecha, García, A. Gómez, \& Latorre, 2009; Valls \& Padrós, 2011; Valls, Soler, \& R. Flecha, 2008) have transformed the appearance and the identity of the neighbourhood. 
The dissemination of evidence-based actions developed in Albacete soon crossed borders. In January 2011, the European Commission published a document entitled Tackling Early School Leaving: A Key Contribution to the Europe 2020 Agenda, based on the analysis of the main successful educational actions in Europe. As stated in the document:

Schools as 'learning communities' agree on a common vision, basic values and objectives of school development. It increases the commitment of pupils, teachers, parents and other stakeholders and supports school quality and development. 'Learning communities' inspire both teachers and pupils to seek improvement and take ownership of their learning processes. It creates favourable conditions also for reducing school dropout and for helping pupils at risk of dropping out. (European Commission, 2011, p. 7)

In June 2011, the Council of the European Union mentioned the learning communities again in a recommendation of policies to reduce the number of pupils dropping out of school:

Intervention policies at the level of the school or training institution could include: (1) Developing schools into learning communities based on a common vision for school development shared by all stakeholders, using the experience and knowledge of all, and providing an open-minded, inspiring and comfortable environment to encourage young people to continue in education and training. (Council of the European Union, 2011)

These two legislative resolutions show the extent of successful actions that emerge from working with the community.

\section{Conclusion}

CMR provides social researchers with powerful tools for the analysis and transformation of social inequalities, starting with including the voices of all stakeholders involved in the research process. This involvement goes past traditionally insurmountable epistemological barriers (interpretative hierarchy, methodological gap, etc.).

Since the 1960s, the struggle between quantitative versus qualitative approaches opened new possibilities for social and educational research, which was adopting new methodological tools increasingly centred on the individual. Vidich and Lyman (2000) state (with a dose of irony, as explained by Denzin \& Lincoln, 
2005 , p. 2) that qualitative research 'was born out of concern to understand "the other" ' (Vidich \& Lyman, 2000, p. 38). Incorporating the perspective of the narrator in qualitative research left important contributions (Garfinkel, 1967; Mills, 1959), amongst others.

Authors such as Freire (1998), Kincheloe (2001), and R. Flecha (2000) have built a theoretical framework that links the rigor of scientific research with its ability to transform social reality. Different methodological approaches have been developed in recent decades, such as action research (Kemmis \& McTaggart, 2005), dialogic inquiry (Wells, 1999), feminist approaches (Butler, 1993/2011), and grounded theory (Glaser \& Strauss, 1967), amongst others. All of these methodologies somehow incorporate the subjective point of view of people who investigate the research process. In a moment of a 'fractured future', as designated by Denzin and Lincoln (2005) in their historical analysis of qualitative methodologies, what differentiates the CMR is that this addition is done from the epistemological and ontological equality of all the actors involved in the research process. Through dialogical knowledge, the cultural intelligence of all subjects can be incorporated.

This article has analysed the case of the transformation of a ghetto school into a magnet school by means of the systematic and rigorous application of the principles of the CMR. It has been demonstrated that the most effective way to transform a ghetto school is to ensure the academic success of its students by providing them with a quality education. Thus, these schools become magnet schools - schools that are desired and chosen by the local community for the education of their children (Aubert, Duque, Fisas, \& Valls, 2004; Siegel-Hawley \& Frankenberg, 2012).

Starting from the epistemological criterion of validity claims in the analysis of social action and decision theory, dialogic organisation created ideal conditions for members of the community and government to make decisions by mutual agreement to transform the school into a centre of educational excellence. In these circumstances, the guidance of CMR aids the social and educational community in overcoming marginalisation and exclusion. The transformation of interactions, the importance of which has already been demonstrated in the definition of social reality (Garfinkel, 1967; Mead, 1934), results in changing the context of everyday life. All those negative classifications (Schutz \& Luckmann, 1973) that were previously uncritically assumed are redefined in this new framework. New opportunities are created, and what was not possible before is now a reality: The community enters the school and becomes part of it. As a result of the inclusion of the personal knowledge of all of the individuals, the school transformation crosses boundaries and spreads throughout the neighbourhood, the city, and across Europe. 
The Roma father who had been in prison but later released thanks to the transformation of his child's school into a learning community where he began to participate as a volunteer explained the change that had been brought about by the application of CMR principles for his own life and based on his own experience. In the European Parliament in Brussels, in front of hundreds of people, political representatives of the European Parliament, representatives of chambers of member states, political parties across Europe, administrative officials, members of organisations, and social partners across Europe, he told his personal story. He recounted his humble origins, his lack of opportunities, etc., but likewise demonstrating his awareness that reality can be changed. Circumstances can be changed with personal effort and the rest of the community, but above all, with the implementation of successful actions emanating from the guidelines and principles of the CMR. As he said on 6 December 2011 in the European Parliament:

From here I want to say to all parents in the world, and all children, that if we had the misfortune of being poor and living in difficult areas, we can change.... Thank you.

\section{Notes}

1. All names used in this article are pseudonyms to protect the privacy and anonymity of informants.

2. 'Merchero' is a mestizo identity referring to those of both Roma and non-Roma descent.

3. For more, visit http://www.eapn-clm.org/biblioteca/documentos/28902.php

\section{References}

Alexiu, T. M., \& Sordé, T. (2011). How to turn difficulties into opportunities: Drawing from diversity to promote social cohesion. International Studies in Sociology of Education, 21, 49-62. doi: 10.1080/09620214.2011.543852

Aubert, A. (2011). Moving beyond social exclusion through dialogue. International Studies in Sociology of Education, 21, 63-75. doi: 10.1080/09620214.2011.543854

Aubert, A., Duque, E., Fisas, M., \& Valls, R. (2004). Dialogar y transformar. Pedagogía crítica del siglo XXI. Barcelona: Graó.

Aubert, A. S., Elboj Saso, C., García Carrión, R., \& García López, J. (2010). Contrato de inclusión dialógica. Revista Interuniversitaria de Formación del Profesorado, 67(24, 1), 101-111.

Beck, U., Giddens, A., \& Lash, S. (1994). Reflexive modernization: Politics, tradition and aesthetics in the modern social order. Stanford, CA: Stanford University Press.

Berger, P. L., \& Luckmann, T. (1968). La construcción social de la realidad. Buenos Aires: Amorrortu. 
Bruner, J. (1996). The culture of education. Cambridge, MA: Harvard University Press. Butler, J. (1993/2011). Bodies that matter. New York: Routledge.

Carcelén, D. (2006, March 8). Los profesores del Colegio San Juan piden protección. La Verdad. Retrieved from http://www.laverdad.es/albacete/pg060308/prensa/noticias/ Albacete/200603/08/ALB-REG-334.html

Castells, M. (1997). La era de la información: Economía, sociedad y cultura. Madrid: Alianza.

Council of the European Union. (2011, July 1). Council recommendation of 28 June 2011 on policies to reduce early school leaving. Official Journal of the European Union, C 191/1-6.

Denzin, N. K., \& Lincoln, Y. S. (2005). The Sage handbook of qualitative research (3rd ed.). Thousand Oaks, CA: Sage.

Díez-Palomar, J., \& Molina, S. (2009). Contribuciones de la educación matemática de las familias a la formación del profesorado. Paper presented at SEIEM Annual Meeting (Sociedad Española de Investigación en Educación Matemática). Santander, España.

European Commission. (2011, January 31). Tackling early school leaving: A key contribution to the Europe 2020 Agenda (COM [2011] 18 final). Brussels, Belgium. Retrieved from http:// ec.europa.eu/education/school-education/doc/earlycom_en.pdf.

Flecha, A., García, R., Gómez, A., \& Latorre, A. (2009). Participation in successful schools: A communicative research study from the INCLUD-ED Project. Cultura y Educación, 21, 183-196.

Flecha, R. (2000). Sharing words: Theory and practice of dialogic learning. Lanham, MD: Rowman \& Littlefield.

Freire, P. (1998). A la sombra de este arbol. Barcelona: El Roure.

García Carrión, R. (2011). Contrato de inclusión dialógica en el colegio La Paz: Una propuesta educativa de éxito para superar la exclusión social. Unpublished doctoral dissertation, University of Barcelona, Barcelona, Spain.

Garfinkel, H. (1967). Studies in ethnomethodology. Englewood Cliffs, NJ: Prentice-Hall.

Glaser, B. G., \& Strauss, A. L. (1967). The discovery of grounded theory: Strategies for qualitative research. London: Weidenfeld and Nicolson.

Gómez, A., Puigvert, L., \& Flecha, R. (2011). Critical communicative methodology: Informing real social transformation through research. Qualitative Inquiry, 17, 235-245. doi: 10. $1177 / 1077800410397802$

Gómez, J., Latorre, A., Sánchez, M., \& Flecha, R. (2006). Metodología comunicativa crítica. Barcelona: El Roure.

Gómez González, A., \& Holford, J. (2010). Contribuciones al éxito educativo desde la metodología comunicativa. Revista Educación y Pedagogía, 22(56), 21-29.

Habermas, J. (1984). The theory of communicative action: Reason and the rationalization of society (Vol. 1, T. A. McCarthy, Trans.). Boston: Beacon Press.

Habermas, J. (1987). The theory of communicative action: Lifeworld and system: A critique of functionalist reason (Vol. 2, T. A. McCarthy, Trans.). Boston: Beacon Press.

INCLUD-ED. (2012). Final INCLUD-ED report: Strategies for inclusion and social cohesion in Europe from education (CIT4-CT-2006-028603). Brussels, Belgium: European Commission.

Kemmis, S., \& McTaggart, R. (2005). Participatory action research: Communicative action and the public sphere. In N. K. Denzin \& Y. S. Lincoln (Eds.), The Sage handbook of qualitative research (3rd ed., pp. 559-603). Thousand Oaks, CA: Sage.

Kincheloe, J. L. (2001). Describing the bricolage: Conceptualizing a new rigor in qualitative research. Qualitative Inquiry, 7, 679-692. doi: 10.1177/107780040100700601 
Mead, G. H. (1934). Mind, self, and society. Chicago: University of Chicago Press.

Mills, C. W. (1959). The sociological imagination. London: Oxford University Press.

Nolan, P., \& Lenski, G. (2004). Human societies: An introduction to macrosociology. Boulder, London: Paradigm Publishers.

Padrós, M., García, R., de Mello, R., \& Molina, S. (2011). Contrasting scientific knowledge with knowledge from the lifeworld: The dialogic inclusion contract. Qualitative Inquiry, 17, 304-312. doi: 10.1177/1077800410397809

Parsons, T. (1952). The social system. London: Tavistock.

Parsons, T. (1966). Societies: Evolutionary and comparative perspectives. Englewood Cliffs, NJ: Prentice-Hall.

Schutz, A., \& Luckmann, T. (1973). Las estructuras del mundo de la vida. Buenos Aires: Amorrortu Editores.

Siegel-Hawley, G., \& Frankenberg, E. (2012, February). Reviving magnet schools: Strengthening a successful choice option. Los Angeles: The Civil Rights Project.

Valls, R., \& Padrós, M. (2011). Using dialogic research to overcome poverty: From principles to action. European Journal of Education, 46, 173-183. doi: 10.1111/j.1465-3435.2011.01473.x

Valls, R., Soler, M., \& Flecha, R. (2008). Lectura dialógica: Interaccion es que mejoran y aceleran la lectura. Revista Iberoamericana de Educación, 46, 71-87.

Vidich, A. J., \& Lyman, S. M. (2000). Qualitative methods: Their history in sociology and anthropology. In N. K. Denzin \& Y. S. Lincoln (Eds.), Handbook of qualitative research (2nd ed., pp. 37-84). Thousand Oaks, CA: Sage.

Vygotsky, L. S. (1978). Mind in society: The development of higher psychological processes. Cambridge, MA: Harvard University Press.

Wells, G. (1999). Dialogic inquiry: Towards a sociocultural practice and theory of education. Cambridge: Cambridge University Press.

\section{About the Authors}

Javier Díez-Palomar, doctor in mathematics education, is a senior researcher (Ramon y Cajal position) in the Department of Mathematics and Sciencies Education at the University of Barcelona. His main areas of research include mathematics education, family involvement, adults' mathematics education, and in-service and preservice teacher training. University of Barcelona, Campus Mundet, Edifici de Llevant, I55, passeig de la Vall d'Hebron, I7I, 08035 Barcelona. E-mail: jdiezpalomar@ub.edu

Tatiana Santos Pitanga is an assistant professor at the Department of Business, University of Girona. Her main areas of research include adult education, community involvement, and teacher training. University of Girona, Faculty of Education and Psychology. Sant Domènec Square, 9, 1707 I Girona. E-mail: tatiana.santos@udg.edu

Pilar Álvarez, is a Ph.D. candidate at the University of Barcelona's Department of Theory and History of Education. Her main lines of research are adult literacy and dialogic reading. CREA - Universitat de Barcelona. Passeig de la Vall d'Hebron, 17I. Edifici de Llevant, planta 0. Despatx 12-13.08035 Barcelona. E-mail: pilaralvarezcif@ub.edu 